\title{
Measuring Contribution of BIM (Building Information Modeling) to the Construction Sustainability Goals
}

\author{
Arjun R. Pandey ${ }^{1}$ and Farzad Shahbodaghlou ${ }^{2}$ \\ 1. CDIP (Chancellor's Doctoral Incentive Program) Scholar, Cal State University, East Bay Hayward, California 94542, USA \\ 2. School of Engineering, California State University, East Bay Hayward, California 94542, USA
}

\begin{abstract}
BIM (building information modeling)" and "sustainability" are two frequently used words in construction and academia today. BIM is a design-oriented tool, which generates a virtual three-dimensional model of a project. Sustainability refers to prudent use of earth's natural resources, and construction sustainability is the application of this principle to building activities. Societies in general and the construction industry in particular — one of the largest in terms of natural resources consumed and waste produced — place high hopes on BIM and the principles of sustainability to reduce consumption and waste and to increase industry productivity. BIM's capabilities and limitations, currently more focused on model creation and energy simulations, are not well understood as they relate to construction sustainability and its goals. No method yet exists to evaluate BIM's contribution comprehensively to construction sustainability goals. This study presents a construction sustainability goals contribution matrix for BIM. The matrix indicates that this contribution may be more limited than it is commonly thought.
\end{abstract}

Key words: BIM, sustainability principles, construction sustainability goals, building ecology.

\section{Introduction}

This intersection of BIM (building information modeling) and sustainability is an area of emerging importance. This is because of growing concerns in many societies about the environment, natural resource utilization and its effect upon their economic growth and development. The primary requirement for sustainable construction is efficient utilization of resources. Construction is the world's primary consumer of materials and energy, consuming about $40 \%$ of materials extracted, and about $30 \% \sim 40 \%$ of primary energy required for operation $[1,2]$.

Information technology has revolutionized many aspects of societies over the last three decades, including agriculture, communication, medicine, music and transportation [3]. The capabilities of design software and its effect on manufacturing and other industries have been significant. However, the construction industry has not yet achieved the

Corresponding author: Arjun R. Pandey, Ph.D. candidate, research fields: construction engineering and management. efficiency, suitability and reduced costs that the manufacturing industry has enjoyed. It is expected that BIM might benefit the construction industry in a similar manner. Most BIM practitioners believe that BIM can achieve construction sustainable outcomes far more than currently achieved in the industry [4]. Therefore, this research assesses BIM's current capabilities as it pertains to obtaining sustainable construction outcomes in the construction industry.

BIM is a data-rich, object-based, intelligent and parametric digital representation of a building, from which views appropriate to various users needs can be extracted and analyzed to generate feedback and improvement of the building's design [5].

\section{Materials and Methods}

\subsection{Materials}

There are three main resources used in this study to develop the assessment tool for BIM's current capabilities as it relates to its corresponding construction sustainability goals. They are: (1) the 
study of Kibert [1, 6] in 2005; (2) the research carried by ISO (International Organization for Standard) [7] in 2006; (3) the study of Graham [8] in 2003.

The primary aspects of sustainable construction are economic, environmental and social [7]. The basic resources needed for construction are materials, energy, water, land and landscape or biota. There is one more resource, namely the ecological system, which is not well understood by construction industry participants. Efforts should be made to integrate this with the building to improve its services, such as heating, cooling, storm-water, waste processing and other environmental amenities [1, 8].

Construction is sustainable only when someone is able to apply the principles of reduce, reuse, recycle to protect nature, eliminate toxic substances, apply life cycle economics in decision making and create a quality built environment. This quality built environment would combine aesthetics, durability and maintainability with the above mentioned base and scarce resources $[1,8]$.

\subsection{Methods}

BIM, a recently developed tool, which utilizes a design oriented software in order to generate a virtual three-dimensional model of a project [3]. Its capabilities have kindled high hopes for industry participants that, in combination with the principles of sustainability, it may revolutionize the construction industry and benefit the environment.

There are numerous software programs available to model a construction project using BIM-architectural applications, MEP (Mechanical Electrical and Plumbing) applications, structural applications, navigation programs and building performance analysis programs. Some of BIM application programs include Revit, V8i, ArchiCAD, Allplan, Vectorworks and Digital Project V1 R4 [9]. Autodesk Navisworks is the software program used for the navigation purpose.

There is also a wide variety of building performance simulation software programs, which have been available on the market for more than 30 years. These include BLAST, BSim, DeST, DOE-2.1E, ECOTECT, Ener-Win, Energy Express, EnergyPlus, IES-VE, HAP, HEED, PowerDomus, SUNREL, Tas, TRACE and TRNSYS [10].

Apart from model creation and energy simulation, there have been several recent innovations, which help scientists to realize this technology's full potential. These include interoperability-of-the-software packages, integration of a carbon accounting tracker and weather data [11]. Also, other software packages exist for selection of optimum building orientation and for evaluation of various skin options and for performance daylight studies of the building's position on the selected site [12]. Additionally, software is available for the use of BIM capabilities related to LCA (life-cycle cost analysis), which perform carbon accounting based on exporting the material schedule for the building and the use of BIM software plug-ins for calculation of operational energy use and carbon emissions [13]. Utilization of the benefit of GIS (geographic information system) and creation of a GIS/BIM IFC (Industry Foundation Classes)-based information exchange to resolve the problem of interoperability are other utilized areas [14]. These are a few of the recent studies done in an attempt to achieve sustainable construction goals.

\subsection{Research Objectives}

The majority of industry participants now use a wide variety of BIM related software available in the market. Many believe that sustainability is the main benefit of BIM, while others consider coordination and visualization to be the main benefits [15]. The purpose is to find a comprehensive tool or technique to facilitate evaluation of BIM's contribution to the sustainability of building design and construction.

The objectives of this study are trying to investigate ways, in which BIM can better assist in achieving construction sustainability and sustainable project development goals. These objectives include: 
(1) to understand what sustainable construction goals and objectives are;

(2) to determine how well BIM is helping the objectives be achieved;

(3) to suggest what BIM capabilities should develop in future.

\subsection{Research Approach}

The literature review led to the development of a matrix (Appendix A), which became the basis of evaluation of the BIM contribution to the construction sustainability goals. This matrix was then applied to evaluate the contribution of BIM to a case study from University of California, Davis, USA, which was designed through the use of BIM (Appendix B).

2.4.1 Existing Evaluation Systems and Their Focus

There have been, since 1992, several initiatives to establish building sustainability related organizations around the world. Some of these include the US Green Building Council, the UK's Association for Environmentally Conscious Builders, the Australian Building Energy Council and similar organizations in Canada, the Netherlands, Japan and South Africa [16].

These independent bodies have proposed assessment programs which rate the environmental performance of a building's design or a completed building as a whole. Some rating programs concentrate on a single environmental performance criterion, such as greenhouse gas emissions (e.g., Australia's Sustainable Energy Development Authority Greenhouse Rating Scheme). The Building Research Establishment in Britain [17] was the innovator of multiple criteria rating schemes and created the BREEAM (British Research Establishment Environmental Assessment Model). The Dutch Institute offers a more technical system, called the NIBE (Environmental Index for Building Biology and Ecology). The SBAT (Sustainable Building Assessment Tool) Assessment Scheme developed by CSIR (Council for Scientific and Industrial Research) in South Africa adds an assessment of a building's social performance to its environmental performance.

In the United States, there are three rating systems in use for the evaluation of commercial buildings: LEED (Leadership in Environmental and Energy Design) [18, 19], Green Globes [20] and ENERGY STAR [21] for Buildings and Plants. Among these, LEED is the most widely-used rating system. However, this rating system has problems, such as encouraging the designer's focus on obtaining the lowest-cost possible to achieve a particular LEED certification, rather than realization of any sustainability goals [22]. Other problems include the conflict among different aspects of LEED's sustainable performance goals [23], e.g., the increasing ratio of glazed surface area versus energy efficiency. Another example would be the conflict that could exist in making a decision for use of regional versus recycled versus reused materials.

As a whole, these rating systems also (show) lack important assessment features for social and ecological aspects of a building's sustainability. An example of this is LCC (life cycle costing), without which any claim to sustainability cannot be credibly made. A building should be sustainable in the totality of its life, which includes its operation, maintenance and eventual demolition, and not just its design and construction

This study offers ways to evaluate current contributions of BIM, as well as potential for contributions in the area of construction and building sustainability.

2.4.2 Evaluating the Contribution of BIM to the Construction Sustainability Goals

This research presents a systematic approach to answer two related questions: Is BIM contributing to the realization of sustainable construction goals? If yes, how much?

As mentioned in Introduction section, the principles of reduce, reuse, recycle and the protection of nature, the elimination of toxic substances, the determination of life cycle economics and the creation of a quality building (its aesthetics, durability and maintainability) are applied to the base and scarce resources of land, 
materials, water, energy, landscape and building ecology $[1,7,8,24]$ to evaluate BIM's present and future capability to realize the construction industry's sustainability goals.

A matrix titled "Evaluation of BIM Capability against the Sustainability Factors" has been developed to assess the contribution of the BIM to the sustainability factors (Appendix A). The scoring matrix was developed based on the findings from a study performed by Kibert [1] and Graham [8]. This matrix identified six parameters as objectives to be achieved: land, materials, water, energy, landscape and building ecology. A sustainably-designed and constructed building is one in which these six parameters are made more sustainable by using the following three principles of conserved or reduced, reused, recycled or eliminated [1].

Economic efficiency, which is to occur over the life of the building, is known as LCC. LCC is the total cost of all resources used in the construction of building-construction, operation and maintenance [25]. Presently, BIM application programs are used to calculate the life cycle costs of building energy use. This calculation is carried out using the energy simulation programs, which are commercially available. These programs have the capacity to share BIM models and can perform tedious energy use calculations.

Construction activities have an especially great impact on ecology and ecological systems. Few studies exist which address the parameters of building ecology. The authors could not find the research done particularly in the intersection of BIM and building ecology.

After the relationships and possible BIM contributions to each parameter were identified, a scoring method was established (Appendix A). Two points were assigned for "Y", no point assigned for "?" or "which is still a subject of study", and no point assigned for " $\mathrm{N}$ ". Equal weights were given to these six parameters because their relative importance is yet to be determined. Therefore, each factor within the six parameters of land, materials, water, energy, landscape and building ecology each received maximum of two points. A total of 84 possible points were available for a project.

Finally, the case study building project "Graduate School of Management and Conference Center, University of California, Davis, USA” was evaluated based on the construction sustainability parameters developed in the matrix. The project scored $0 / 14$ on land usage, $10 / 14$ on material usage, $8 / 14$ on water usage, $14 / 14$ on energy usage, $0 / 14$ on landscape usage and $0 / 14$ on building ecology (Appendix A). This means the project scored 32 out of the potential total possible score of 84 on sustainability.

\section{Results and Discussion}

The following findings of the study are shown in the matrix presented in the Appendix A:

- BIM makes significant contributions to three design parameters: materials, water and energy;

- BIM is not presently contributing to the achievement of conservation of land or improvement of building ecology systems;

- BIM is not yet directly contribute to the realization of sustainability in areas of achieving elimination of toxins, more accurate life cycle costing or increased quality of the building resources.

\section{Conclusions and Recommendations}

The following conclusions are drawn from the study:

- BIM is contributing to the realization of achieving reductions in three of six design parameters: reuse and recycling of construction materials and reduction in water and energy use;

- The three design parameters to which BIM cannot yet contribute-land, landscape and building ecology—are the next capabilities which BIM should develop;

- BIM utilizes its potential reasonably well in 
optimizing energy consumption;

- BIM is used to a lesser extent in optimizing material and water consumption.

The authors offer the following recommendations for further research and development:

- Authors plan to do further work with design and construction firms to test and validate the tool to increase its reliability. The result will be presented in a future paper;

- Further research needs to be done on integration of land, landscape and building ecology into BIM capabilities;

- Further research can be done to utilize BIM for optimizing material and water consumption.

\section{Acknowledgments}

The authors would like to thank Mr. Strachan Forgan for the case study data of the project "Graduate School of Management and Conference Center, University of California, Davis, USA”. Finally, author would also like to thank Mr. John J. Burger (Juris Doctor), for his assistance.

\section{References}

[1] Kibert, C. J. 2005. "Resource Conscious Building Design Methods." Sustainable Built Environment 1: 1-11.

[2] Roodman, D., and Lenssen, N. 1995. A Building Revolution: How Ecology and Health Concerns are Transforming Construction. Washington, D.C.: World Watch Institute.

[3] Autodesk Inc. 2011. "Improving Building Industry Results through Integrated Project Delivery and Building Information Modeling” Autodesk Inc. Accessed May 20, 2014. http://www.autodesk.com/.

[4] McGraw Hill. 2010. "Building Information Modeling for Sustainable Design.” In Smart Market Report. Autodesk, Inc. Accessed December 1, 2011. http://construction.com/market_research/FreeReport/Gree nBIM/MHC_GreenBIM_SmartMarket_Report_2010.pdf.

[5] Azhar, S., Brown, J., and Farooqui, R. 2008. "BIM-Based Sustainability Analysis: An Evaluation of Building Performance Analysis Software." Associated Schools of Construction. Accessed February 1, 2014. http://ascpro.ascweb.org/chair/paper/CPRT125002009.pdf.

[6] Kibert, C. J. 2003. "Sustainable Construction at the Start of the 21st Century." Special Issues Article in: The Future of Sustainable Construction, IEJC (International Electronic Journal of Construction).

[7] ISO (International Organization for Standard). 2006. "ISO/DIS 15392. Sustainability in Building Construction-General Principles. ISO/TS 21929-1.” In Sustainability Indicators. Geneva: ISO.

[8] Graham, P. 2003. Building Ecology: First Principles for a Sustainable Built Environment. Boston: Wiley-Blackwell.

[9] Khalfan, M. M. A., Bouchlaghem, N. M., Anumba, C. J., and Carrillo, P. M. 2003. "Knowledge Management for Sustainable Construction: The C-San D Project." Presented at Construction Research Congress, Honolulu, Hawaii, USA.

[10] Crawley, D. B., Hand, J. W., Kummert, M., and Griffith, B. T. 2008. "Contrasting the Capabilities of Building Energy Performance Simulation Programs." Building and Environment 43 (4): 661-73.

[11] Krygiel, E., and Nies, B. 2008. Green BIM: Successful Sustainable Design with Building Information Modeling. 1st ed. New York: Wiley.

[12] Azhar, S. 2011. "Building Information Modeling (BIM): Trends, Benefits, Risks and Challenges for the AEC Industry." Leadership Management Engineering 11 (3): 241-52.

[13] Stadel, A., Eboli, J., Ryberg, A., Mitchell, J., and Spatari, S. 2011. "Intelligent Sustainable Design: Integration of Carbon Accounting and Building Information Modeling." Journal of Professional Issues in Engineering Education Practice 137 (2): 51-4.

[14] Przybyla, J. 2010. "The Next Frontier for BIM: Interoperability with GIS." Journal of Building Information Modeling 2010 (Fall): 14-8. Accessed February 12, 2012. https://www.wbdg.org/pdfs/jbim_fall 10.pdf.

[15] Bynum, P., Issa, R., and Olbina, S. 2013. "Building Information Modeling in Support of Sustainable Design and Construction." Journal of Construction Engineering and Management ASCE 139: 24-34.

[16] NIBE (Netherland Instituut Voor Bouwbiologie en Ecologie). 2013. "NIBE's Environmental Classifications of Building Products" Netherland Instituut Voor Bouwbiologie en Ecologie. Accessed May 20, 2014. http://www.nibe.org/nlhttp://www.nibe.org/nl.

[17] Stewart, R., and Cooper, I. 2006. Constructing Excellence: Definition of Sustainable Construction. Manchester: Centre for Construction Innovation.

[18] USGBC (U.S. Green Building Council). 2010. "LEED V4 for Building Design and Construction" USGBC. Accessed March 2012. http://www.usgbc.org/http://www.usgbc.org/

[19] USGBC. 2008. "LEED for Homes Rating System Corrections." In Clarifications and Exemplary 


\section{Sustainability Goals}

Performance Rulings LEED for Homes. Washington, D.C.: USGBC.

[20] Green Globes. 2012. "Green Globes for NC (New Construction)." Green Globes. Accessed March 12, 2014. http://www.greenglobes.com/home.asp.

[21] ENERGY STAR. 2012. "National Energy Performance Rating System.” ENERGY STAR. Accessed March 12, 2012. https://www.energystar.gov/ia/business/healthcare/ natl_energy_rating_system.pdf.

[22] Navarro, M. 2009. Some Buildings Not Living Up to Green Label. New York: New York Times. Accessed March 10,
2014. http://www.nytimes.com/.

[23] Nature. 2009. "Overrated Ratings." Nature 461 (7261): 146-54. Accessed May 20, 2014. http://www.nature.com/nature/journal/v461/n7261/full/46 1146a.html.

[24] Stewart, R., and Cooper, I. 2006. Constructing Excellence: Definition of Sustainable Construction. Manchester: Centre for Construction Innovation.

[25] Mearig, T., Coffee, N., and Morgan, M. 1999. Life Cycle Cost Analysis Handbook. 1st ed. Alaska: State of Alaska. 
Appendix A: Evaluation of BIM capability against the construction sustainability factors.

\begin{tabular}{|c|c|c|c|c|c|c|}
\hline \multicolumn{7}{|c|}{ Land (natural and agricultural land, environmental amenity and biodiversity) } \\
\hline $\mathrm{Y}$ & ? & $\mathrm{N}$ & Sustainability principles & Sustainability factors & Current BIM capability & Possible points: 14 \\
\hline & ? & & Conservation & $\begin{array}{l}\text { Site selection; alternative transportation; storm water } \\
\text { erosion and sedimentation control; urban infill and } \\
\text { sprawl; greenfield }\end{array}$ & $\begin{array}{l}\text { BIM application, Google Earth and GIS may help in } \\
\text { future }\end{array}$ & 2 \\
\hline & $?$ & & Reuse & Brownfield redevelopment; alternative transportation & $\begin{array}{l}\text { BIM application, Google Earth and GIS may help in } \\
\text { future }\end{array}$ & 2 \\
\hline & ? & & Recycle & Brownfield redevelopment; alternative transportation & $\begin{array}{l}\text { BIM application, Google Earth and GIS may help in } \\
\text { future }\end{array}$ & 2 \\
\hline & ? & & Protect nature & $\begin{array}{l}\text { Protect or restore habitat; maximize open space; } \\
\text { greenfield; floodplains; tree preservation; erosion } \\
\text { and sedimentation control }\end{array}$ & $\begin{array}{l}\text { BIM application, Google Earth and GIS may help in } \\
\text { future }\end{array}$ & 2 \\
\hline & ? & & Eliminate toxics & $\begin{array}{l}\text { Heat island effect; light pollution; chemical and } \\
\text { pollutant source control; environmental tobacco } \\
\text { smoke control }\end{array}$ & $\begin{array}{l}\text { Visualization; day-lighting (BIM application and energy } \\
\text { simulation programs) }\end{array}$ & 2 \\
\hline & & $\mathrm{N}$ & Life cycle costing & None & $\begin{array}{l}\text { Not aware of any existing BIM tool—area of future } \\
\text { development }\end{array}$ & 2 \\
\hline & ? & & $\begin{array}{l}\text { Quality-aesthetic, durability, } \\
\text { maintainability }\end{array}$ & $\begin{array}{l}\text { Storm-water design; development density and } \\
\text { community connectivity; greenfield; floodplains }\end{array}$ & $\begin{array}{l}\text { BIM application, Google Earth and GIS may help in } \\
\text { future }\end{array}$ & 2 \\
\hline \multicolumn{7}{|c|}{ Materials (all construction materials, e.g., concrete, steel, wood, glass) } \\
\hline Y & & & Conservation & $\begin{array}{l}\text { Rapidly renewable material; regional materials; } \\
\text { minimized use of raw materials }\end{array}$ & Create schedule and quantities (BIM application) & 2 \\
\hline $\mathrm{Y}$ & & & Reuse & Building reuse; material reuse & Create schedule and quantities (BIM application) & 2 \\
\hline $\mathrm{Y}$ & & & Recycle & Recycled content; construction waste management & Create schedule and quantities (BIM application) & 2 \\
\hline \multirow[t]{3}{*}{$\mathrm{Y}$} & & & Protect nature & Recycled content; construction waste management & Create schedule and quantities (BIM application) & 2 \\
\hline & ? & & Eliminate toxics & $\begin{array}{l}\text { Low emitting materials; construction waste } \\
\text { management; environmental tobacco smoke control }\end{array}$ & $\begin{array}{l}\text { Not aware of any existing BIM tool—area of future } \\
\text { development }\end{array}$ & 2 \\
\hline & ? & & Life cycle costing & None & $\begin{array}{l}\text { Not aware of any existing BIM tool—future } \\
\text { development area }\end{array}$ & 2 \\
\hline $\mathrm{Y}$ & & & $\begin{array}{l}\text { Quality—aesthetic, durability, } \\
\text { maintainability }\end{array}$ & Construction waste management; regional material & Create schedule and quantities (BIM application) & 2 \\
\hline
\end{tabular}




\begin{tabular}{|c|c|c|c|c|c|c|}
\hline \multicolumn{7}{|c|}{ Water (potable water sources: surface and subsurface, water consumption) } \\
\hline $\mathrm{Y}$ & $?$ & $\mathrm{~N}$ & Sustainability principles & Sustainability factors & Current BIM capability & Possible points: 14 \\
\hline $\mathrm{Y}$ & & & Conservation & $\begin{array}{l}\text { Water efficient landscaping; storm-water design; } \\
\text { water consumption }\end{array}$ & Water usage estimator or water review (GBS, IES-VE) & 2 \\
\hline $\mathrm{Y}$ & & & Reuse & $\begin{array}{l}\text { Innovative wastewater technology; water use } \\
\text { reduction }\end{array}$ & Water usage estimator or water review (GBS, IES-VE) & 2 \\
\hline $\mathrm{Y}$ & & & Recycle & $\begin{array}{l}\text { Innovative wastewater technology; water use } \\
\text { reduction; water treatment }\end{array}$ & Water usage estimator or water review (GBS, IES-VE) & 2 \\
\hline \multirow[t]{3}{*}{ Y } & & & Protect nature & $\begin{array}{l}\text { Innovative wastewater technology; water use } \\
\text { reduction }\end{array}$ & Water usage estimator or water review (GBS, IES-VE) & 2 \\
\hline & & $\mathrm{N}$ & Life cycle costing & None & $\begin{array}{l}\text { Not aware of any existing BIM tool—area of future } \\
\text { development }\end{array}$ & 2 \\
\hline & & N & $\begin{array}{l}\text { Quality—aesthetic, durability, } \\
\text { maintainability }\end{array}$ & None & $\begin{array}{l}\text { Not aware of any existing BIM tool—area of future } \\
\text { development }\end{array}$ & 2 \\
\hline \multicolumn{7}{|c|}{ Energy (envelope resistance heat transfer-conduction, convection and radiation, renewable energy design and passive design) } \\
\hline $\mathrm{Y}$ & ? & $\mathrm{N}$ & Sustainability principles & Sustainability factors & Current BIM capability & Possible points: 14 \\
\hline $\mathrm{Y}$ & & & Conservation & $\begin{array}{l}\text { Renewable energy; green power; onsite renewable } \\
\text { energy; power demand reduction }\end{array}$ & $\begin{array}{l}\text { Photovoltaic potential; wind energy potential; low } \\
\text { carbon technology (BIM application and energy } \\
\text { simulation programs) }\end{array}$ & 2 \\
\hline $\mathrm{Y}$ & & & Reuse & Renewable energy; minimizing re-heat and re-cool & $\begin{array}{l}\text { Photovoltaic potential; wind energy potential; low } \\
\text { carbon technology (BIM application, and energy } \\
\text { simulation programs) }\end{array}$ & 2 \\
\hline $\mathrm{Y}$ & & & Recycle & $\begin{array}{l}\text { Renewable energy; green power; onsite renewable } \\
\text { energy; power demand reduction; minimizing re-heat } \\
\text { and re-cool }\end{array}$ & $\begin{array}{l}\text { Photovoltaic potential; wind energy potential; low } \\
\text { carbon technology (BIM application and energy } \\
\text { simulation programs) }\end{array}$ & 2 \\
\hline $\mathrm{Y}$ & & & Protect nature & $\begin{array}{l}\text { Renewable energy; green power; onsite renewable } \\
\text { energy }\end{array}$ & $\begin{array}{l}\text { Photovoltaic potential; wind energy potential; low } \\
\text { carbon technology (BIM application, and energy } \\
\text { simulation programs) }\end{array}$ & 2 \\
\hline $\mathrm{Y}$ & & & Eliminate toxics & $\begin{array}{l}\text { Light pollution; refrigerant management; heat island } \\
\text { effect; light reduction control; exterior luminaires } \\
\text { and controls; acoustic analysis }\end{array}$ & $\begin{array}{l}\text { Low carbon technology; visualization; acoustic analysis } \\
\text { (BIM application, energy simulation programs) }\end{array}$ & 2 \\
\hline $\mathrm{Y}$ & & & Life cycle costing & Value/cost analysis & $\begin{array}{l}\text { LCC and LCA (life cycle assessment) of energy } \\
\text { components (energy simulation programs) }\end{array}$ & 2 \\
\hline $\mathrm{Y}$ & & & $\begin{array}{l}\text { Quality-aesthetic, durability, } \\
\text { maintainability }\end{array}$ & None & $\begin{array}{l}\text { Whole building energy, thermal, daylight, solar } \\
\text { radiation; shows and reflection analysis (energy } \\
\text { simulation programs) }\end{array}$ & 2 \\
\hline
\end{tabular}




\begin{tabular}{|c|c|c|c|c|c|c|}
\hline \multicolumn{7}{|c|}{ Landscape (control external building loads, processing waste, absorbing storm water) } \\
\hline \multirow[t]{8}{*}{$\mathrm{Y}$} & $?$ & $\mathrm{~N}$ & Sustainability principles & Sustainability factors & Current BIM capability & Possible points: 14 \\
\hline & & $\mathrm{N}$ & Conservation & $\begin{array}{l}\text { Site selection; alternative transportation; storm water } \\
\text { erosion and sedimentation control; urban infill and } \\
\text { sprawl; greenfield }\end{array}$ & $\begin{array}{l}\text { Not aware of any existing BIM tool—area of future } \\
\text { development }\end{array}$ & 2 \\
\hline & & $\mathrm{N}$ & Reuse & $\begin{array}{l}\text { Construction waste management; storm-water } \\
\text { technology }\end{array}$ & $\begin{array}{l}\text { Not aware of any existing BIM tool-area of future } \\
\text { development }\end{array}$ & 2 \\
\hline & & $\mathrm{N}$ & Recycle & $\begin{array}{l}\text { Construction waste management; storm-water } \\
\text { technology }\end{array}$ & $\begin{array}{l}\text { Not aware of any existing BIM tool—area of future } \\
\text { development }\end{array}$ & 2 \\
\hline & & $\mathrm{N}$ & Protect nature & $\begin{array}{l}\text { Site selection; alternative transportation; storm water } \\
\text { erosion and sedimentation control; urban infill and } \\
\text { sprawl; greenfield }\end{array}$ & $\begin{array}{l}\text { Not aware of any existing BIM tool—area of future } \\
\text { development }\end{array}$ & 2 \\
\hline & & $\mathrm{N}$ & Eliminate toxics & $\begin{array}{l}\text { Exterior light pollution; prescriptive light } \\
\text { requirement; alternative transport—alter fuel }\end{array}$ & $\begin{array}{l}\text { Not aware of any existing BIM tool—area of future } \\
\text { development }\end{array}$ & 2 \\
\hline & & $\mathrm{N}$ & Life cycle costing & None & $\begin{array}{l}\text { Not aware of any existing BIM tool—area of future } \\
\text { development }\end{array}$ & 2 \\
\hline & & $\mathrm{N}$ & $\begin{array}{l}\text { Quality—aesthetic, durability, } \\
\text { maintainability }\end{array}$ & $\begin{array}{l}\text { Prescriptive light requirement; development density } \\
\text { and community connectivity; greenfield; floodplains }\end{array}$ & $\begin{array}{l}\text { Not aware of any existing BIM tool—area of future } \\
\text { development }\end{array}$ & 2 \\
\hline \multicolumn{7}{|c|}{ Building ecological system (interactions of organisms, populations and biological species, including humans with living and non-living environment) } \\
\hline \multirow[t]{8}{*}{ Y } & ? & $\mathrm{N}$ & Sustainability principles & Sustainability factors & Current BIM capability & Possible points: 14 \\
\hline & & $\mathrm{N}$ & Conservation & Protection and restoration of habitat & $\begin{array}{l}\text { Not aware of any existing BIM tool—area of future } \\
\text { development }\end{array}$ & 2 \\
\hline & & N & Reuse & None & $\begin{array}{l}\text { Not aware of any existing BIM tool—area of future } \\
\text { development }\end{array}$ & 2 \\
\hline & & $\mathrm{N}$ & Recycle & None & $\begin{array}{l}\text { Not aware of any existing BIM tool—area of future } \\
\text { development }\end{array}$ & 2 \\
\hline & & $\mathrm{N}$ & Protect nature & None & $\begin{array}{l}\text { Not aware of any existing BIM tool—area of future } \\
\text { development }\end{array}$ & 2 \\
\hline & & $\mathrm{N}$ & Eliminate toxics & Ozone depletion; global warming; direct heating & $\begin{array}{l}\text { Not aware of any existing BIM tool—area of future } \\
\text { development }\end{array}$ & 2 \\
\hline & & $\mathrm{N}$ & Life cycle costing & None & $\begin{array}{l}\text { Not aware of any existing BIM tool—area of future } \\
\text { development }\end{array}$ & 2 \\
\hline & & $\mathrm{N}$ & $\begin{array}{l}\text { Quality—aesthetic, durability, } \\
\text { maintainability }\end{array}$ & None & $\begin{array}{l}\text { Not aware of any existing BIM tool—area of future } \\
\text { development }\end{array}$ & 2 \\
\hline \multicolumn{6}{|c|}{ Total possible points } & 84 \\
\hline
\end{tabular}


Appendix B: Evaluation of UC Davis GSM and CC Project using the matrix.

\begin{tabular}{|c|c|c|c|c|c|c|}
\hline \multicolumn{7}{|c|}{ Land (natural and agricultural land; environmental amenity and biodiversity) } \\
\hline $\mathrm{Y}$ & ? & $\mathrm{N}$ & Sustainability principles & Sustainability factors & Current BIM capability & Points received: 0 \\
\hline & ? & & Conservation & $\begin{array}{l}\text { Site selection; alternative transportation; storm } \\
\text { water erosion and sedimentation control; urban } \\
\text { infill and sprawl; greenfield }\end{array}$ & $\begin{array}{l}\text { BIM application, Google Earth and GIS may help in } \\
\text { future }\end{array}$ & 0 \\
\hline & ? & & Reuse & $\begin{array}{l}\text { Brownfield redevelopment; alternative } \\
\text { transportation }\end{array}$ & $\begin{array}{l}\text { BIM application, Google Earth and GIS may help in } \\
\text { future }\end{array}$ & 0 \\
\hline & ? & & Recycle & $\begin{array}{l}\text { Brownfield redevelopment; alternative } \\
\text { transportation }\end{array}$ & $\begin{array}{l}\text { BIM application, Google Earth, and GIS may help in } \\
\text { future }\end{array}$ & 0 \\
\hline & ? & & Protect nature & $\begin{array}{l}\text { Protect or restore habitat; maximize open space; } \\
\text { greenfield; floodplains; tree preservation; erosion } \\
\text { and sedimentation control }\end{array}$ & $\begin{array}{l}\text { BIM application, Google Earth, and GIS may help in } \\
\text { future }\end{array}$ & 0 \\
\hline & ? & & Eliminate toxics & $\begin{array}{l}\text { Heat island effect; light pollution; chemical and } \\
\text { pollutant source control; environmental tobacco } \\
\text { smoke control }\end{array}$ & $\begin{array}{l}\text { Visualization; day-lighting (BIM application, and } \\
\text { energy simulation programs) }\end{array}$ & 0 \\
\hline & & $\mathrm{N}$ & Life cycle costing & None & $\begin{array}{l}\text { Not aware of any existing BIM tool_-area of future } \\
\text { development }\end{array}$ & 0 \\
\hline & ? & & $\begin{array}{l}\text { Quality-aesthetic, durability, } \\
\text { maintainability }\end{array}$ & $\begin{array}{l}\text { Storm-water design; development density and } \\
\text { community connectivity; greenfield; floodplains }\end{array}$ & $\begin{array}{l}\text { BIM application, Google Earth and GIS may help in } \\
\text { future }\end{array}$ & 0 \\
\hline \multicolumn{7}{|c|}{ Materials (all construction materials e.g. concrete, steel, wood, glass) } \\
\hline $\mathrm{Y}$ & & & Conservation & $\begin{array}{l}\text { Rapidly renewable material; regional materials; } \\
\text { minimized use of raw materials }\end{array}$ & Create schedule and quantities (BIM application) & 2 \\
\hline $\mathrm{Y}$ & & & Reuse & Building reuse; material reuse & Create schedule and quantities (BIM application) & 2 \\
\hline $\mathrm{Y}$ & & & Recycle & Recycled content; construction waste management & Create schedule and quantities (BIM application) & 2 \\
\hline \multirow[t]{3}{*}{$\mathrm{Y}$} & & & Protect nature & Recycled content; construction waste management & Create schedule and quantities (BIM application) & 2 \\
\hline & ? & & Eliminate toxics & $\begin{array}{l}\text { Low emitting materials; construction waste } \\
\text { management; environmental tobacco smoke control }\end{array}$ & $\begin{array}{l}\text { Not aware of any existing BIM tool—area of future } \\
\text { development }\end{array}$ & 0 \\
\hline & ? & & Life cycle costing & None & $\begin{array}{l}\text { Not aware of any existing BIM tool—future } \\
\text { development area }\end{array}$ & 0 \\
\hline $\mathrm{Y}$ & & & $\begin{array}{l}\text { Quality—aesthetic, durability, } \\
\text { maintainability }\end{array}$ & Construction waste management; regional material & Create schedule and quantities (BIM application) & 2 \\
\hline
\end{tabular}




\begin{tabular}{|c|c|c|c|c|c|c|}
\hline \multicolumn{7}{|c|}{ Water (potable water sources: surface and subsurface, water consumption) } \\
\hline $\mathrm{Y}$ & ? & $\mathrm{N}$ & Sustainability principles & Sustainability factors & Current BIM capability & Points received: 8 \\
\hline $\mathrm{Y}$ & & & Conservation & $\begin{array}{l}\text { Water efficient landscaping; storm-water design; } \\
\text { water consumption }\end{array}$ & $\begin{array}{l}\text { Water usage estimator or water review (GBS, } \\
\text { IES-VE) }\end{array}$ & 2 \\
\hline $\mathrm{Y}$ & & & Reuse & $\begin{array}{l}\text { Innovative wastewater technology; water use } \\
\text { reduction }\end{array}$ & $\begin{array}{l}\text { Water usage estimator or water review (GBS, } \\
\text { IES-VE) }\end{array}$ & 2 \\
\hline $\mathrm{Y}$ & & & Recycle & $\begin{array}{l}\text { Innovative wastewater technology; water use } \\
\text { reduction; water treatment }\end{array}$ & $\begin{array}{l}\text { Water usage estimator or water review (GBS, } \\
\text { IES-VE) }\end{array}$ & 2 \\
\hline \multirow[t]{3}{*}{ Y } & & & Protect nature & $\begin{array}{l}\text { Innovative wastewater technology; water use } \\
\text { reduction }\end{array}$ & $\begin{array}{l}\text { Water usage estimator or water review (GBS, } \\
\text { IES-VE) }\end{array}$ & 2 \\
\hline & & $\mathrm{N}$ & Life cycle costing & None & $\begin{array}{l}\text { Not aware of any existing BIM tool—area of future } \\
\text { development }\end{array}$ & 0 \\
\hline & & $\mathrm{N}$ & $\begin{array}{l}\text { Quality—aesthetic, durability, } \\
\text { maintainability }\end{array}$ & None & $\begin{array}{l}\text { Not aware of any existing BIM tool—area of future } \\
\text { development }\end{array}$ & 0 \\
\hline \multicolumn{7}{|c|}{ Energy (envelope resistance heat transfer-conduction, convection and radiation, renewable energy design and passive design) } \\
\hline $\mathrm{Y}$ & ? & $\mathrm{N}$ & Sustainability principles & Sustainability factors & Current BIM capability & Points received: 14 \\
\hline $\mathrm{Y}$ & & & Conservation & $\begin{array}{l}\text { Renewable energy; green power; onsite renewable } \\
\text { energy; power demand reduction }\end{array}$ & $\begin{array}{l}\text { Photovoltaic potential; wind energy potential; low } \\
\text { carbon technology (BIM application and energy } \\
\text { simulation programs) }\end{array}$ & 2 \\
\hline $\mathrm{Y}$ & & & Reuse & Renewable energy; minimizing re-heat and re-cool & $\begin{array}{l}\text { Photovoltaic potential; wind energy potential; low } \\
\text { carbon technology (BIM application, and energy } \\
\text { simulation programs) }\end{array}$ & 2 \\
\hline $\mathrm{Y}$ & & & Recycle & $\begin{array}{l}\text { Renewable energy; green power; onsite renewable } \\
\text { energy; power demand reduction; minimizing } \\
\text { re-heat and re-cool }\end{array}$ & $\begin{array}{l}\text { Photovoltaic potential; wind energy potential; low } \\
\text { carbon technology (BIM application, and energy } \\
\text { simulation programs) }\end{array}$ & 2 \\
\hline $\mathrm{Y}$ & & & Protect nature & $\begin{array}{l}\text { Renewable energy; green power; onsite renewable } \\
\text { energy }\end{array}$ & $\begin{array}{l}\text { Photovoltaic potential; wind energy potential; low } \\
\text { carbon technology (BIM application, and energy } \\
\text { simulation programs) }\end{array}$ & 2 \\
\hline $\mathrm{Y}$ & & & Eliminate toxics & $\begin{array}{l}\text { Light pollution; refrigerant management; heat } \\
\text { island effect; light reduction control; exterior } \\
\text { luminaires and controls; acoustic analysis }\end{array}$ & $\begin{array}{l}\text { Low carbon technology; visualization; acoustic } \\
\text { analysis (BIM application, energy simulation } \\
\text { programs) }\end{array}$ & 2 \\
\hline $\mathrm{Y}$ & & & Life cycle costing & Value/cost analysis & $\begin{array}{l}\text { LCC and LCA of energy components (energy } \\
\text { simulation programs) }\end{array}$ & 2 \\
\hline $\mathrm{Y}$ & & & $\begin{array}{l}\text { Quality—aesthetic, durability, } \\
\text { maintainability }\end{array}$ & None & $\begin{array}{l}\text { Whole building energy, thermal, daylight, solar } \\
\text { radiation; shows and reflection analysis (energy } \\
\text { simulation programs) }\end{array}$ & 2 \\
\hline
\end{tabular}




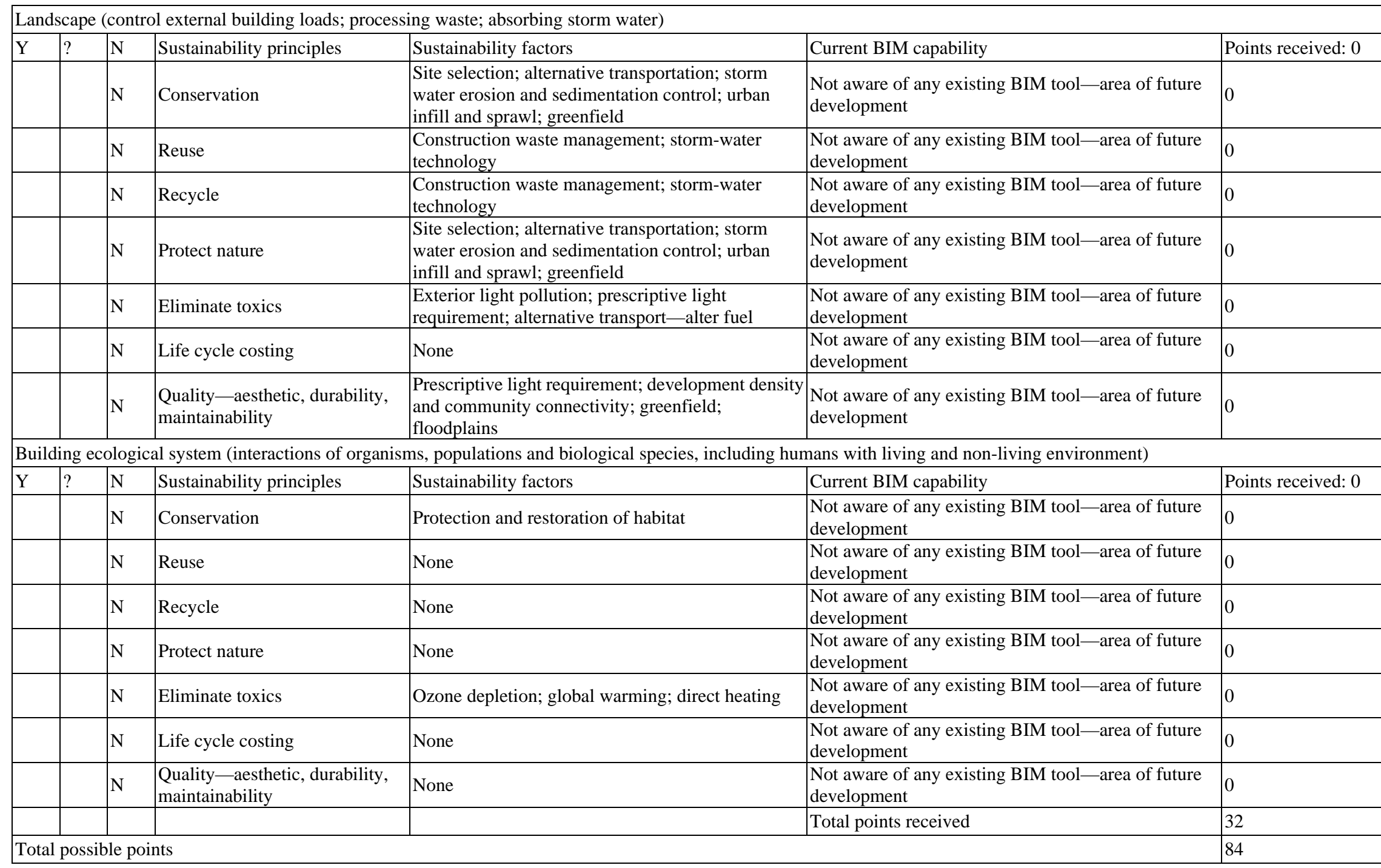

